\title{
JEKK
}

Jurnal Epidemiologi Kesehatan Komunitas

3 (2), 2018, 54-62

\section{Gaya Hidup yang Berpengaruh terhadap Kejadian Stroke Iskemik pada \\ Usia Kurang dari 45 Tahun (Studi Pada BLUD \\ RSUD Cut Nyak Dhien Meulaboh Kabupaten Aceh Barat Provinsi Aceh)}

\author{
Arif Iskandar*, Suharyo Hadisaputro ${ }^{* *}$, Dwi Pudjonarko ${ }^{* * *}$, Suhartono ${ }^{* * * *}$, \\ Dodik Tugasworo Pramukarso \\ "Universitas Muhammadiyah Aceh, ${ }^{* *}$ Politeknik Kesehatan Semarang, ${ }^{* * *}$ Fakultas Kedokteran Undip, \\ ${ }^{* * * * * *}$ Fakultas Kesehatan Masyarakat Undip, ${ }^{* * * * * * *}$ RSUP Dr. Kariadi
}

\begin{abstract}
Background: Ischemic stroke that occurs at the age of less than 45 years accounts for about 5 until 10 percent of the total stroke. This is influenced by changes in the life-style of modern society, such as changes in the pattern of food consumption, lazy to move, and smoking habits. This study aims to examine the effect of life-style on ischemic stroke at less than 45 years old people.

Method: This study uses observational method with design of cases and controls. The samples are 86 observations consisting of 43 cases and 43 controls. Cases are patients with ischemic stroke less than 45 years of age and controls are non-stroke patients of neurology who are less than 45 years old.

Results: The results show that the habit of consuming food containing high fat $(p=0,032$, $\mathrm{OR}=3,744,95 \% \mathrm{CI}=1,124-12,468)$ and smoking habit $(\mathrm{p}=0,019, \mathrm{OR}=3.859,95 \% \mathrm{CI}=1,250$ $11,911)$ affect the occurrence of ischemic stroke at age less than 45 years. However, the habit of consuming red meat, consuming foods containing high salt, consuming drugs, and lack of physical activity do not affect the occurrence of ischemic stroke at age less than 45 years.

Conclusion: The habits of consuming food containing high fat and smoking affect the occurrence of ischemic stroke at age less than 45 years after hypertension, heart disease, and diabetes mellitus are controlled.
\end{abstract}

Keywords : Life-style,ischemic stroke; red meat; high fat in foods; high salt in foods; smoking; physicalactivity

*Penulis korespondensi : arif.iskand@yahoo.com 


\section{Pendahuluan}

Stroke merupakan salah satu penyakit non infeksi yang dapat menjadi penyebab cacat nomor satu dan kematian nomor dua dunia. ${ }^{1}$ Berdasarkan data $\mathrm{WHO}$, penderita stroke berjumlah 15 juta orang di dunia, dengan jumlah kematian sebanyak 5 juta orang dan 5 juta orang lainnya mengalami kecacatan yang permanen setiap tahunnya. ${ }^{2}$

Stroke merupakan penyakit serebrovaskular yang banyak ditemukan tidak hanya pada negara-negara maju tapi juga pada negara-negara berkembang. Stroke merupakan penyebab utama kecacatan di negara-negara barat. Di Belanda, stroke menduduki peringkat ketiga sebagai penyebab DALY's (Disability Adjusted Life Years = kehilangan bertahuntahun usia produktif). ${ }^{3}$ Di Amerika, seseorang mengalami serangan stroke dalam waktu setiap 40 detik dan setiap 4 menit seseorang meninggal karena stroke. ${ }^{4}$ Orang yang mengalami stroke di Amerika Serikat diperkirakan 795.000 orang setiap tahunnya, dengan 610.000 orang mendapat serangan stroke untuk pertama kalinya dan 185.000 orang dengan serangan stroke berulang. Seseorang meninggal akibat stroke di Amerika Serikat didapati dalam setiap 3 menit. $^{5}$

Penyakit stroke belakangan ini tidak hanya menyerang kelompok usia tua saja, melainkan juga terjadi pada kelompok usia muda yang masih produktif. Jumlah penderita stroke di seluruh dunia yang berusia dibawah 45 tahun terus meningkat. Konferensi ahli saraf internasional di Inggris melaporkan terdapat lebih dari 1000 penderita stroke berusia kurang dari 30 tahun. Stroke menduduki peringkat utama penyebab kecacatan di Inggris.

Jumlah penderita stroke lebih banyak terdapat pada negara-negara berkembang di Asia dibandingkan negara maju. Di Cina, angka kejadian stroke mencapai 1,5-2 juta setiap tahun. Stroke iskemik merupakan jenis stroke yang paling banyak, dan penyakit kompleks yang disebabkan oleh faktor genetik, faktor lingkungan, dan hubungan keduanya. ${ }^{6}$ Sebuah studi di Iran menyatakan bahwa kejadian stroke iskemik pada usia muda dari 8/100.000, frekuensi stroke usia muda (15-45 tahun) adalah 21\% dari 3.055 pasien stroke. Beberapa studi terhadap stroke iskemik di Asia menyatakan laki-laki lebih dominan daripada perempuan (71-76\%).

Di Indonesia, jumlah penduduk terkena serangan stroke mencapai 500.000 orang dalam setiap tahun, di antaranya 2,5\% atau 125.000 orang meninggal, dan sisanya cacat ringan maupun berat. Kejadian stroke iskemik sekitar $80 \%$ dari seluruh total kasus stroke, sedangkan kejadian stroke hemoragik hanya sekitar $20 \%$ dari seluruh total kasus stroke. ${ }^{8}$ Prevalensi stroke di Indonesia mengalami peningkatan yaitu dari 8,3 per 1000 penduduk pada tahun 2007 menjadi 12,1 per 1000 penduduk pada tahun 2013 . Daerah yang memiliki prevalensi stroke tertinggi adalah Nanggroe Aceh Darussalam (16,6 per 1.000 penduduk) dan yang terendah adalah Papua (3,8 per 1.000 penduduk).,10

Penyebab tingginya angka kejadian stroke di Aceh disebabkan karena pola hidup masyarakat yang tidak sehat, seperti malas bergerak, makanan berlemak dan kolesterol tinggi, sehingga banyak di antara mereka mengidap penyakit yang menjadi pemicu timbulnya serangan stroke. Penelitian ini bertujuan untuk mengetahui gaya hidup yang berpengaruh terhadap kejadian stroke iskemik pada usia kurang dari 45 tahun.

\section{Metode}

Jenis penelitian yang digunakan adalah penelitian analitik observasional dengan pendekatan case control study, yaitu membandingkan antara kelompok kasus dengan kelompok kontrol. Penelitian ini dilaksanakan pada bulan Juli sampai Agustus 2017 di Badan Layanan Umum Daerah Rumah Sakit Umum Daerah Cut Nyak Dhien Meulaboh dengan persetujuan dari Komisi Etik Penelitian Kesehatan (KEPK) Fakultas Kedokteran Universitas Diponegoro-RSUP. Dr. Kariadi Semarang No.384/EC/FKRSDK/VI/2017. Populasi studi adalah penderita stroke iskemik berusia kurang dari 45 tahun yang berobat di BLUD Rumah Sakit Umum Daerah Cut Nyak Dhien Meulaboh Kabupaten Aceh Barat. 
Pengambilan sampel dilakukan secara consecutive sampling dengan jumlah sampel terdiri dari 43 kasus dan 43 kontrol. Inklusi kasus yaitu pasien stroke iskemik berusia kurang dari 45 tahun dan inklusi kontrol yaitu pasien neurologi yang bukan penderita stroke berusia kurang dari 45 tahun. Data dikumpulkan dengan menggunakan kuisioner dan catatan rekam medik. Analisis data dilakukan dengan menggunakan software SPSS versi 21 meliputi analisis univariat, bivariat dan multivariat pada tingkat signifikan $p<0,05$.

\section{Hasil}

Tabel 1. menunjukkan tidak ada perbedaan karakteristik subyek antara kasus dan kontrol pada jenis kelamin, pekerjaan, dan pendidikan (nilai $p>0,05$ ), kecuali pada umur responden terdapat perbed aan ( $\mathrm{p}<$ 0,05 ). Rerata umur responden pada kelompok kasus adalah 42 tahun umur termuda 29 tahun dan umur tertua 44 tahun. Sedangkan pada kelompok kontrol rerata umur responden adalah 41 tahun, dengan umur termuda 30 tahun dan umur tertua 44 tahun. Distribusi jenis kelamin laki- laki terbanyak terdapat pada kelompok kasus yaitu $72,1 \%$, sedangkan jenis kelamin pe rempuan terbanyak terdapat pada kelompok kontrol yaitu $41,9 \%$ Pekerjaan yang dimiliki responden sebagian besar adalah PNS, yang terdapat pada kelompok kasus sebanyak $46,5 \%$ dan kelompok kontrol sebanyak $32,6 \%$. Tingkat pendi- dikan responden pada kelompok kasus terbanyak adalah S1 yaitu 34,9\%, sedang- kan pada kelompok kontrol terbanyak adalah SMA yaitu $32,6 \%$.

Tabel 1. Distribusi Karakteristik Responden Menurut Umur, Jenis Kelamin, Pekerjaan, dan Pendidikan

\begin{tabular}{|c|c|c|c|c|c|c|}
\hline \multirow{2}{*}{ No. } & \multirow{2}{*}{$\begin{array}{l}\text { Karakteristik } \\
\text { Responden }\end{array}$} & \multicolumn{2}{|c|}{ Kasus } & \multicolumn{2}{|c|}{ Kontrol } & \multirow[b]{2}{*}{$\mathrm{p}$} \\
\hline & & $\mathrm{N}$ & $(\%)$ & $\mathrm{N}$ & $(\%)$ & \\
\hline \multirow[t]{6}{*}{1.} & Umur $^{\mathrm{a}}$ & 40,79 & & 39,53 & & \multirow{6}{*}{0,047} \\
\hline & Mean & 42,00 & & 41,00 & & \\
\hline & Modus & 44 & & $40^{\mathrm{a}}$ & & \\
\hline & Std.Deviasi & 3,556 & & 3,801 & & \\
\hline & Minimum & 29 & & 30 & & \\
\hline & Maksimum & 44 & & 44 & & \\
\hline \multirow[t]{9}{*}{2.} & Jenis Kelamin $^{\mathrm{b}}$ & & & & & \multirow{3}{*}{0,175} \\
\hline & Laki-laki & 31 & 72,1 & 25 & 58,1 & \\
\hline & Perempuan & 12 & 27,9 & 18 & 41,9 & \\
\hline & \multicolumn{6}{|l|}{ Pekerjaan $^{\mathrm{b}}$} \\
\hline & PNS & 20 & 46,5 & 14 & 32,6 & \multirow{5}{*}{0,573} \\
\hline & Swasta & 10 & 23,3 & 9 & 20,9 & \\
\hline & Petani & 3 & 7,0 & 6 & 14,0 & \\
\hline & Nelayan & 2 & 4,7 & 2 & 4,7 & \\
\hline & Ibu Rumah Tangga & 8 & 18,6 & 12 & 27,9 & \\
\hline \multirow[t]{6}{*}{3.} & Pendidikan $^{\mathrm{b}}$ & & & & & \multirow{6}{*}{0,866} \\
\hline & $\mathrm{SD}$ & 2 & 4,7 & 2 & 4,7 & \\
\hline & SMP & 8 & 18,6 & 10 & 23,3 & \\
\hline & SMA & 11 & 25,6 & 14 & 32,6 & \\
\hline & D3 & 7 & 16,3 & 6 & 14,0 & \\
\hline & S1 & 15 & 34,9 & 11 & 25,6 & \\
\hline
\end{tabular}

Keterangan : ${ }^{\mathrm{a}}$ Uji Mann-Whitney, ${ }^{\mathrm{b}}$ Uji Chi-Square 
Hasil analisis bivariat dengan menggunakan uji chi-square diperoleh varia- bel independen yang berpengaruh terhadap kejadian stroke iskemik pada usia kurang dari 45 tahun yaitu konsumsi daging merah $(\mathrm{p}=0,018 ; \mathrm{OR}=2,855 ; 95 \% \mathrm{CI}=1,189-6,854)$, kebiasaan konsumsi makanan yang mengandungtinggi lemak $(\mathrm{p}=0,007 ; \mathrm{OR}=3$, 606;95\%CI=1,398-9,299), dan kebiasaan merokok $(p=0,003 ; \mathrm{OR}=3,867 ; 95 \% \quad \mathrm{CI}=$ $1,581-9,458)$.
Variabel confounding yang berpengaruh terhadap kejadian stroke iskemik pada usia kurang dari 45 tahun yaitu hipertensi $(\mathrm{p}=0,001 ; \mathrm{OR}=4,308 ; 95 \%$ $\mathrm{CI}=1,745-10,635)$, penyakit jantung $(\mathrm{p}=$ 0,$003 ; \quad \mathrm{OR}=4,176 ; \quad 95 \% ; \quad \mathrm{CI}=1,578$ 11,054), dan diabetes mellitus $(\mathrm{p}=0,004$; $\mathrm{OR}=3,958 ; 95 \% \mathrm{CI}=1,535-10,206)$.

Tabel 2 Ringkasan analisis bivariat variabel independen dan variabel confounding terhadap kejadian stroke iskemik pada usia kurang dari 45 tahun

\begin{tabular}{|c|c|c|c|c|}
\hline No. & Variabel & OR & $95 \% \mathrm{CI}$ & $P$ \\
\hline \multicolumn{5}{|c|}{ Variabel Independen } \\
\hline & Konsumsi daging merah & 2,855 & $1,189-6,854$ & 0,018 \\
\hline & $\begin{array}{l}\text { Kebiasaan konsumsi makanan yang } \\
\text { mengandung tinggi lemak }\end{array}$ & 3,606 & $1,398-9,299$ & 0,007 \\
\hline & $\begin{array}{l}\text { Kebiasaan konsumsi makanan yang } \\
\text { mengandung tinggi garam }\end{array}$ & 1,478 & $0,620-3,525$ & 0,378 \\
\hline & Kebiasaan merokok & 3,867 & $1,581-9,458$ & 0,003 \\
\hline & Mengkonsumsi/menghisap ganja & 1,478 & $0,430-5,080$ & 0,534 \\
\hline & Kurang aktivitas fisik & 2,158 & $0,847-5,496$ & 0,104 \\
\hline \multicolumn{5}{|c|}{ Variabel Confounding } \\
\hline 1. & Hipertensi & 4,308 & $1,745-10,635$ & 0,001 \\
\hline & Penyakit jantung & 4,176 & $1,578-11,054$ & 0,003 \\
\hline & Diabetes mellitus & 3,958 & $1,535-10,206$ & 0,004 \\
\hline & Obesitas & 1,384 & $0,554-3,456$ & 0,486 \\
\hline
\end{tabular}

Analisis multivariat dilakukan untuk mengetahui pengaruh variabel independen dan variabel confounding terhadap kejadian stroke iskemik pada usia kurang dari 45 tahun. Analisis multivariat menggunakan uji regresi logistik dengan metode backward LR pada tingkat kemaknaan 95\%. Variabel yang telah dianalisis secara bivariat dan memiliki nilai $\mathrm{p}<0,25$ dimasukkan ke dalam analisis multivariat. Hasil uji regresi logistik menunjukkan variabel independen yang berpengaruh terhadap kejadian stroke iskemik yaitu kebiasaan konsumsi makanan yang mengandung tinggi lemak $(\mathrm{p}=0,032$; $\mathrm{OR}=3,744 ; 95 \% \quad \mathrm{CI}=1,124-12,468)$, dan kebiasaan merokok $(\mathrm{p}=0,019$; $\mathrm{OR}=3,859$; $95 \% \mathrm{CI}=1,250-11,911)$. Variabel confounding yang berpengaruh terhadap kejadian stroke iskemik yaitu hipertensi ( $\mathrm{p}=0,002$; $\mathrm{OR}=7,456 ; 95 \% \mathrm{CI}=2,146-25,907)$, penyakit jantung $(p=0,029 ; O R=4,017 ; 95 \% \mathrm{CI}=$ $1,156-13,957)$, dan diabetes mellitus ( $\mathrm{p}=$ 0,010; OR=5,427;95\% CI=1,495-19,707). 
Tabel 3. Hasil analisis regresi logistik faktor yang mempengaruhi kejadian stroke iskemik pada usia kurang dari 45 tahun

\begin{tabular}{cllrrc}
\hline No. & \multicolumn{1}{c}{ Variabel } & B & Nilai p & Exp (B) / OR & \multicolumn{1}{c}{$95 \%$ CI } \\
\hline 1. & Kebiasaan konsumsi makanan & 1,320 & 0,032 & 3,744 & $1,124-12,468$ \\
& yang mengandung tinggi lemak & & & & \\
2. Kebiasaan merokok & 1,350 & 0,019 & 3,859 & $1,250-11,911$ \\
3. & Hipertensi & 2,009 & 0,002 & 7,456 & $2,146-25,907$ \\
4. Diabetes mellitus & 1,390 & 0,029 & 4,017 & $1,156-13,957$ \\
5. Penyakit jantung & 1,691 & 0,010 & 5,427 & $1,495-19,707$ \\
& Constant & $-3,661$ & & & \\
\hline
\end{tabular}

\section{Pembahasan}

Hasil analisis multivariat menunjukkan adanya pengaruh antara kebia saan konsumsi makanan yang mengandung tinggi lemak terhadap kejadian stroke iskemik pada usia kurang dari 45 tahun $(\mathrm{p}=0,032 ; \mathrm{OR}=3,744 ; 95 \% \mathrm{CI}=1,124-12,468)$ Orang yang mengkonsumsi makanan yang mengandung tinggi lemak $\geq 3$ kali/minggu berisiko 3,744 kali untuk terjadinya stroke iskemik dibandingkan dengan orang yang mengkonsumsi makanan yang mengandung tinggi lemak $<3$ kali/ minggu.

Hasil penelitian ini sesuai dengan penelitian Purwaningtiyas yang menyatakan sekitar $75 \%$ kasus stroke di usia dewasa muda selalu mengkonsumsi makanan tinggi lemak dan kolesterol dibandingkan dengan $68,4 \%$ responden yang jarang mengkonsumsi makanan tinggi lemak dan kolesterol, sehingga ditemukan adanya hubungan antara konsumsi makanan tinggi lemak dan kolesterol dengan kejadian stroke di usia muda ( $\mathrm{p}=0,000 ; \mathrm{OR}=6,655 ; 95 \%$ $\mathrm{CI}=2,925-15,139){ }^{11}$

Berbeda dengan penelitian Cheng et al untuk mencari bukti terhadap hubungan antara asupan asam lemak jenuh dengan risiko stroke ditemukan bahwa asupan asam lemak jenuh yang tinggi berkaitan dengan penurunan risiko stroke $(\mathrm{RR}=0,89 ; 95 \%$ $\mathrm{CI}=0,82-0,96){ }^{12}$

Makanan yang mengandung tinggi lemak bila dikonsumsi secara berlebihan dapat meningkatkan kadar kolesterol dalam darah. Kolesterol total mencakup kolesterol LDL dan HDL serta lemak lain di dalam darah dengan kadar tidak boleh lebih dari 200 $\mathrm{mg} / \mathrm{dl}$. Semakin tinggi kolesterol di dalam darah akan memperbesar kemungkinan terjadi penimbunan pada dinding pembuluh darah, sehingga menyebabkan saluran pembuluh darah menjadi sempit dan suplai darah ke otak terganggu. ${ }^{13}$ Kolesterol membentuk bekuan darah dan plak yang menyumbat arteri dan akhirnya memutuskan aliran darah ke jantung dan ke otak. Hal inilah yang dapat menyebabkan terjadinya serangan jantung dan stroke. ${ }^{14}$

Kebiasaan merokok mempunyai pengaruh terhadap kejadian stroke iskemik pada usia kurang dari 45 tahun $(\mathrm{p}=0,019$; $\mathrm{OR}=3,859 ; 95 \% \mathrm{CI}=1,250-11,911)$. Risiko terjadinya stroke iskemik pada orang yang mempunyai kebiasaan merokok 3,859 kali lebih besar dibandingkan dengan orang yang tidak merokok. Hasil penelitian ini sejalan dengan penelitian Bonita et al yang menyatakan bahwa perokok aktif memiliki risiko stroke sebanyak 4 kai lipat dibandingkan dengan orang yang tidak mero$\operatorname{kok}(\mathrm{OR}=4,14 ; 95 \% 95 \% \mathrm{CI}=3,04-5,63){ }^{15}$

Jasminka et al menemukan bahwa merokok merupakan salah satu faktor risiko dengan frekuensi tersering sebanyak $57,76 \%$ dari pasien stroke usia muda yang diteliti. ${ }^{16}$ Risiko stroke akan bertambah sekitar 2-3 kali pada perokok dibandingkan bukan perokok dan baru hilang setelah berhenti merokok selama 5 sampai 10 tahun. $^{17}$

Merokok meningkatkan risiko terkena stroke empat kali lipat. Hal ini berlaku bagi semua jenis rokok (sigaret, pipa, atau cerutu) dan untuk semua tipe stroke, terutama perdarahan subaraknoid dan stroke iskemik. Merokok menyebabkan penyempitan dan 
pengerasan arteri di seluruh tubuh (termasuk yang ada di otak, jantung, dan tungkai), sehingga merokok mendorong terjadinya arterosklerosis, mengurangi aliran darah, dan menyebabkan darah mulai menggumpal. Merokok juga meningkatkan pembentukan dan pertumbuhan aneurisma intrakranium. ${ }^{18}$

Merokok dikaitkan dengan keadaan hiperkoagulasi pada manusia. Hal ini ditandai dengan peningkatan pelepasan tromboksan yang menyebabkan peningkatan aktivasi trombosit dan degenerasi endotelium vaskular sehingga mendorong pembentukan plak penghasil trombus. Nikotin tampaknya tidak bertanggung jawab langsung atas perubahan ini. Namun, ada kemungkinan pembakaran asap rokok yang menyebabkan pembentukan tromboemboli, sehingga menyebabkan stroke iskemik. ${ }^{19}$

Hasil analisis multivariat menunjukkan bahwa hipertensi merupakan perancu yang memiliki pengaruh terhadap kejadian stroke iskemik pada usia kurang dari 45 tahun $(\mathrm{p}=0,002 ; \mathrm{OR}=7,456 ; 95 \%$ $\mathrm{CI}=2,146-25,907)$. Orang yang mempunyai riwayat penyakit hipertensi berisiko 7,456 kali lebih besar terjadinya stroke iskemik dibandingkan dengan orang yang tidak memiliki riwayat hipertensi. Hasil penelitian ini sejalan dengan penelitian Supanc et al yang menyatakan bahwa hipertensi merupakan faktor risiko independen untuk terjadinya stroke iskemik $(p=0,001$; $\mathrm{OR}=2,839 ; 95 \% \mathrm{CI}=1,519-5,305) .{ }^{20}$ Penelitian ini juga sejalan dengan penelitian Rosmaria yang mendapatkan adanya hubungan hipertensi dengan kejadian stroke $(\mathrm{p}=0,000 ; \mathrm{OR}=8,81 ; 95 \% \mathrm{CI}=3,507$ $22,164)^{21}$

Hipertensi mempercepat proses arteriosklerosis, sehingga meningkatkan kemungkinan lesi serebral yang berhubungan dengan stenosis dan emboli yang berasal dari pembuluh besar ekstrakranial, lengkungan aorta dan dari jantung. Hipertensi mempercepat proses arteriosklerosis yang biasanya dimulai di arteri ekstraserebralis lebih besar, terutama pada bifurkasi karotis. Prosesnya menyebar ke lingkaran willis dan seiring dengan waktu arteri intraserebral yang lebih kecil juga akan terlibat. Stenosis karotid tingkat tinggi dapat membahayakan sirkulasi serebral, dan emboli dari plak di arteri karotis dan vertebralis dapat menyebabkan serangan iskemik transient dan infark otak. ${ }^{22}$

Hasil analisis multivariat menunjukkan bahwa penyakit jantung merupakan perancu yang memiliki pengaruh terhadap kejadian stroke iskemik $(\mathrm{p}=0,029$; $\mathrm{OR}=4,017 ; 95 \% \mathrm{CI}=1,156-13,957)$. Orang yang mempunyai kelainan jantung berisiko 4,017 kali lebih besar terjadinya stroke iskemik dibandingkan dengan orang yang tidak memiliki kelainan jantung. Hal ini sejalan dengan penelitian Nildawati yang menyatakan bahwa pada orang yang memiliki kelainan jantung berisiko terkena stroke non hemoragik 3,7 kali lebih besar dibandingkan dengan orang yang tidak mempunyai kelainan penyakit jantung $(\mathrm{p}=0,011 ; \mathrm{OR}=3,7 ; 95 \% \mathrm{CI}=1,3-9,9) .{ }^{23}$

Penelitian Riyadina, mengemukakan bahwa penyakit jantung koroner merupakan salah satu determinan utama penyakit stroke yang mempunyai risiko 2 kali lebih besar untuk mengalami penyakit stroke dibandingkan dengan tidak mempunyai penyakit jantung koroner $(\mathrm{p}=0,001$; $\mathrm{OR}=2,74 ; 95 \% \mathrm{CI}=1,51-4,99){ }^{24}$

Peran kelainan jantung dalam meningkatkan risiko stroke non hemoragik adalah terbentuknya emboli yang berasal dari katup jantung, dinding jantung dan ruang jantung. Di samping itu, gangguan curah jantung karena kelainan ritme yang hebat atau dekompensasi menyebabkan penurunan perfusi otak. Kelainan jantung yang paling sering terjadi yaitu atrial non valvuler yang bersama-sama dengan emboli serebri menyebabkan stroke. Atrial fibrilasi non valvuler sebagai penyebab utama emboli mempunyai variansi yang luas yaitu mulai dari lone atrial fibrilation sampai ventrikel dengan gagal jantung kongestif. Fibrilasi atrium sendiri dikaitkan dengan peningkatan risiko stroke sebesar 3 sampai 4 kali lipat setelah disesuaikan dengan faktor risiko vaskular lainnya. ${ }^{25}$

Selain itu, gagal jantung (CHF) merupakan faktor risiko utama stroke iskemik. Tingkat morbiditas dan mortalitas stroke lebih tinggi terdapat pada pasien CHF dibandingkan dengan pasien non CHF. Gagal 
jantung kronis dapat meningkatkan risiko pembentukan trombus yang disertai peningkatan risiko stroke 2 sampai 3 kali lipat. ${ }^{26}$

Hasil analisis multivariat menunjukkan bahwa diabetes mellitus merupakan perancu yang memiliki pengaruh terhadap kejadian stroke iskemik $(\mathrm{p}=0,010$; $\mathrm{OR}=5,427 ; 95 \% \mathrm{CI}=1,495-19,707)$. Orang yang mempunyai riwayat diabetes mellitus berisiko 5,427 kali lebih besar terjadinya stroke iskemik dibandingkan dengan orang yang tidak memiliki riwayat diabetes mellitus. Hasil penelitian ini sejalan dengan penelitian Kristiyawati dkk, yang mendapatkan $61,2 \%$ dari penderita stroke mengalami diabetes mellitus. Kristiyawati menyatakan ada hubungan yang signifikan antara diabetes mellitus dengan kejadian stroke $(\mathrm{p}=0,003){ }^{27}$

Penelitian ini juga sejalan dengan penelitian Khairatunnisa di RSU H. Sahudin Kutacane Kabupaten Aceh Tenggara, yaitu orang yang menderita diabetes mellitus mempunyai risiko terkena stroke 4,12 kali lebih besar dibandingkan dengan orang yang tidak menderita diabetes mellitus $(\mathrm{p}=0,003$; $\mathrm{OR}=4,12 ; 95 \% \mathrm{CI}=1,69-10,04) .{ }^{28}$ Berbeda dengan penelitian Alchuriyah yang dilakukan pada pasien RS Brawijaya Surabaya, menyatakan bahwa diabetes mellitus tidak mempunyai pengaruh terhadap kejadian stroke di usia muda. ${ }^{29}$

Penderita diabetes mellitus mengalami disfungsi endotel yang disebabkan oleh metabolisme yang abnormal. Disfungsi endotel kemudian meningkatkan vasokontriksi, proinflamasi, dan proses protrombik yang berkontribusi pada pengembangan plak dan ruptur sehingga terjadi aterosklerosis. Patofisiologi stroke pada penderita diabetes belum diketahui secara jelas, tetapi dapat terlihat bahwa terdapat efek aterosklerosis pada pembuluh darah otak besar dan kecil. ${ }^{30}$

Orang dengan diabetes tipe 2 memiliki kerentanan terhadap aterosklerosis dan peningkatan prevalensi faktor risiko aterogenik, terutama hipertensi, obesitas, dan lipid darah abnormal. Sejak tahun 1990, prevalensi orang-orang yang didiagnosis dengan diabetes naik $61 \%$, dengan peningkatan 8,2\% dari tahun 2000 sampai 2001. Pada tahun 2001, ditemukan 11,1 juta orang Amerika menderita diabetes yang didiagnosis oleh dokter, dan diperkirakan 5,1 juta tambahan memiliki penyakit yang tidak terdiagnosis. Studi case control pada pasien stroke dan studi epidemiologi prospektif telah mengkonfirmasi adanya efek independen diabetes terhadap stroke iskemik, dengan peningkatan RR pada penderita diabetes mulai dari 1,8 kali lipat sampai hampir 6 kali lipat.

\section{Kesimpulan}

Kebiasaan konsumsi makanan yang mengandung tinggi lemak dan kebiasaan merokok terbukti berpengaruh terhadap kejadian stroke iskemik pada usia kurang dari 45 tahun setelah dikendalikan dengan hipertensi, penyakit jantung, dan diabetes mellitus.

\section{Ucapan Terimakasih}

Terimakasih kepada pihak Rumah Sakit Umum Daerah Cut Nyak Dhien Meulaboh Kabupaten Aceh Barat telah memberi kesempatan sebagai lokasi penelitian.

\section{Daftar Pustaka}

1. Feigin VL. 2007. Stroke in Developing Countries: Can The Epidemic be Stopped and Outcomes Improved?

2. The Lancet Neurology;6(2).pp.94-97. WHO. 2010. Global Burden of Stroke. [11 Januari 2017]; Available from: http://www.who.int/cardiovascular_dis eases/en/cvd_atlas_15_burden_stroke.p df.

3. Janssen AWM, de Leeuw FE, Janssen MCH. 2011. Risk Factors for Ischemic Stroke and Transient Ischemic Attack in Patients Under Age 50. Journal of Thrombosis and Thrombolysis. 31(1): pp.85-91.

4. Benjamin EJ, Blaha MJ, Chiuve SE, Cushman M, Das SR, Deo R, et al. 2017. Heart Disease and Stroke Statistics. Update: A Report From the American Heart Association. AHA Journal;136(24).pp.1-45. 
5. Lloyd-Jones D, Adams RJ, Brown TM, Carnethon M, Dai S, De Simone G, et al. 2010. Heart Disease and Stroke Statistics. Update A Report From the American Heart Association. AHA Journal;121(7).pp.46-215.

6. Xu C, Wang F, Wang B, Li X, Li C, Wang D, et al. 2010. Minor Allele C of Chromosome 1p32 Single Nucleotide Polymorphism rs 11206510 Confers Risk of Ischemic Stroke in the Chinese Han Population. Stroke ;41(8).pp.1587-1592.

7. Wasay M, Kaul S, Menon B, Venketasubramanian N, Gunaratne P, Khalifa A, et al.2010.Ischemic Strok in Young Asian Women: Risk Factors, Subtypesand Outcome. Cerebrovascular Diseases;30(4).pp.418-422.

8. Yayasan Stroke Indonesia. 2012. YASTROKI Tangani Masalah Stroke di Indonesia.[15 Februari 2017]; Available from: http://www.yastroki. or.id/read. php?id=20.

9. Kemenkes RI. 2007. Riset Kesehatan Dasar Jakarta: Badan Penelitian dan Pengembangan.

10. Kemenkes RI. 2013. Riset Kesehatan Dasar Jakarta: Badan Penelitian dan Pengembangan.

11. Purwaningtiyas P. 2014. Hubungan Antara Gaya Hidup Dengan Kejadian Stroke Usia Dewasa Muda di RSUD dr. Moewardi Surakarta. Surakarta:Universitas Muhammadiyah Surakarta

12. Cheng P, Wang J, Shao W, Liu M, Zhang H. 2016. Can Dietary Saturated Fat be Beneficial in Prevention of Stroke Risk? A Meta-Analysis. Neurological Sciences;37(7).pp.1089-1098.

13. Junaidi I . 2011. Stroke, Waspadai Ancamannya. Yogyakarta: ANDI

14. Wolf PA, Kannel WB. 2011. Epidemiology of Stroke. In: Mohr JP, Wolf PA, Grotta JC, Moskowitz MA, Mayberg M R, Kummer Rv, editors. Stroke; Pa thophysiology, diagnosis, and management. Philadelphia: Elsevier Saunders pp. 198-218.

15 Bonita R, Duncan J, Truelsen T, Jackson RT, Beaglehole R. 1999. Passive Smoking as Well as Active Smoking Increases The Risk of Acute Stroke. Tobacco Control;8.pp.156-160.

16. Jasminka D, Azra A, Merita T-È, Todoroviæ L. 2011. Stroke At A Younger Age. Acta ClinCroat;50(2).pp.185-191.

17. Tugasworo D.2000. Faktor Risiko yang Berkaitan dengan Stroke Non Hemoragik di Rumah Sakit Kariadi dan Rumah Sakit Elizabeth. Semarang: Universitas Diponegoro.

18. Feigin V. 2004. When Lightning Strikes: An Illustrated Guide To Stroke PreventionVAnd Recovery. New Zealand: HarperCollins

19. Hawkins BT, Brown RC, P.Davis T. 2002. Smoking and ischemic stroke: a role for nicotine? TRENDS in Pharmacological Sciences;23(2).pp.78-82.

20. Supanc V, Sonicki Z, Vukasovic I, Solter VV, Zavoreo I, Kes VB. 2004. The Role of Classic Risk Factors and Prothrombotic Factor Gene Mutations in Ischemic Stroke Risk Development in Young and Middle-Aged Individuals. Journal of Stroke and Cerebrovascular Diseases. ;23(3).pp.171-176.

21. Rosmaria O. 2012. Analisis faktor risiko kejadian stroke pada usia dewasa produktif di RSUP dr. Wahidin Sudirohusodo Kota Makassar. Makassar:Universitas Hasanuddin Johansson BB . Hypertension 1992.

22. Mechanisms Causing Stroke. Clinical and Experimental Pharmacology and Physiology;26(7).pp.563-565. Nildawati. 2012. Beberapa Faktor

23. Risiko Yang Mempengaruhi Terhadap Kejadian Stroke Non Haemoragik (Studi Kasus di Stroke Center Rumah Sakit Khusus Daerah Propinsi Sulawesi Selatan). Semarang: Universitas Diponegoro

24. Riyadina W, Rahajeng E. 2013. Determinan Penyakit Stroke. Jurnal Kesehatan Masyarakat Nasional; 7(7). pp. 324-330. 
25. Goldstein LB, Adams R, Becker K, Furberg CD, Gorelick PB, Hademenos $\mathrm{G}$, et al. Primary Prevention of IschemicStroke. A Statement for Healthcare Professionals From the Stroke Council of the American Heart Association. 2001;103(1).pp.163-182.

26. Haeusler KG, Laufs U, Endres $M$. 2011. Chronic Heart Failure and Ischemic Stroke.

27. Kristiyawati SP, Irawati D, Hariyati TS. Faktor Risiko Yang Berhubungan Dengan Kejadian Stroke Di Rumah Sakit Panti Wilasa Citarum Semarang. Jurnal Ilmu Keperawatan dan Kebidanan. 2009;1(1).pp.1-7.
28. Khairatunnisa, Sari DM. 2017. Faktor Risiko yang Berhubungan dengan Kejadian Stroke pada Pasien di RSU H.Sahudin Kutacane Kabupaten Aceh Tenggara. Jumantik; 2(1). pp.60-70

29. Alchuriyah S, Wahjuni CU. 2014. Faktor Risiko Kejadian Stroke Usia Muda pada Pasien Rumah Sakit Brawijaya. Surabaya: Universitas Airlangga

30. Hewitt J, Castilla Guerra L, Fernández Moreno MdC, Sierra C. 2012. Diabetes and Stroke Prevention: A Review.Stroke Research and Treatment. 